\title{
IMMUNOLOGIC AND BIOLOGIC CHARACTERIZATION OF ANTISERA TO BEEF THYROTROPIN PREPARATIONS *
}

\author{
By SIDNEY C. WERNER, BEATRICE C. SEEGAL ANd ELLIOTT F. OSSERMAN \\ (From the Departments of Medicine and of Microbiology, Columbia University College of \\ Physicians and Surgeons, New York, N. Y.)
}

(Submitted for publication May 18, 1960 ; accepted September 15, 1960)

Sensitive immunologic techniques and more purified preparations of bovine pituitary thyrotropin have made it possible to re-examine the question of whether thyrotropin acts as an antigen upon injection into heterologous species. This possibility was first indicated by Werner $(1,2)$ in 1936, to explain the loss of responsiveness to thyrotropin which Collip and Anderson (3) previously had observed to follow repeated injection of crude pituitary extracts. These latter workers, having demonstrated that serum from such refractory animals could neutralize the effect of thyrotropin upon the thyroid in nonrefractory animals, postulated that thyrotropic stimulation had caused an increase in the titer of an antihormone acting to preserve homeostasis by exerting an effect opposite to that of the thyrotropin. In conflict with the antihormone thesis, however, were the observations (4) that a flavianic acid preparation of thyrotropin did not evoke refractoriness, could stimulate the thyroid of the refractory animal, and could not be neutralized by the serum of refractory animals-supporting the view that antibody to a foreign protein, rather than an antihormone, had been induced. To date, however, there has been no in vitro demonstration of a circulating antibody specific for thyrotropin (5), nor is it known whether highly purified thyrotropic preparations evoke antibody formation.

The results of the present experiments suggest that in the rabbit, bovine thyrotropin itself, or a closely associated and as yet not separable protein, does induce the formation of precipitating antibody; and that antisera containing such antibodies can neutralize the thyrotropic effect of the hormone.

* Aided by grants A-8 (C8-11), National Institutes of Health, Division of Arthritis and Metabolism; Institutional Grant of the National Cancer Institute (CY 2332); and National Heart Institute Grant H 3923.

\section{METHODS}

Thyrotropic hormone preparations. Three bovine thyroid-stimulating hormone ( $\mathrm{TSH}$ ) preparations were used in these studies. One, in clinical use under the trade name Thytropar, contained approximately 1 international unit (IU) per mg ("Armour"). The two other preparations contained greater activity ranging from 5 to $25 \mathrm{IU}$ per $\mathrm{mg}$, and were provided through the kindness of Dr. Peter G. Condliffe and Dr. Rohert W. Bates ("Condliffe"), and Drs. John L. Pierce and M. E. Carsten ("Pierce"). Both of these latter preparations were concentrated on anion diethylaminoethyl (DEAE) and cation (carboxymethyl cellulose) exchange resins (6, 7) with some variations in methodology between laboratories. A mouse pituitary tumor thyrotropin preparation was made available by Dr. Condliffe and Dr. Bates (8) and a preparation of human thyrotropin by Dr. John Bakke and Dr. Peter Heidemann.

Pituitary hormone preparations other than TSH. A number of pituitary hormone preparations other than $\mathrm{TSH}$ were tested for cross reaction with the anti-TSH sera. The sources of these preparations are listed in Table II. All preparations termed "Wilhelmi" were provided by both Dr. Alfred E. Wilhelmi and Dr. Stanley Ellis. The bovine growth hormone and prolactin preparations were obtained as a gift of the Endocrine Study Section, National Institutes of Health.

Preparation of antisera. The antisera used for the precipitin and in vivo neutralization studies were developed in rabbits. Fifteen animals were immunized: 9 with Armour TSH, and 3 animals each with the Condliffe and Pierce TSH preparations, respectively. Three IU of thyrotropin was incorporated in $1.0 \mathrm{ml}$ of Freund adjuvant and injected intracutaneously in multiple sites (9). The injections were repeated 2 or 3 times, at weekly or biweekly intervals. A total of 9 or $12 \mathrm{U}$ was given to each rabbit. Ten days after the final injection, the animals were exsanguinated under sterile conditions and the sera were separated and stored without preservative at $4^{\circ} \mathrm{C}$.

After the initial precipitin studies, absorption of the antisera to TSH with bovine serum was routinely performed. This was accomplished in the following manner : $0.05 \mathrm{ml}$ of bovine serum was added to each $1.0 \mathrm{ml}$ of antiserum and allowed to stand 5 to 7 days at $4^{\circ} \mathrm{C}$. The precipitate was then removed by centrifugation, and another $0.05 \mathrm{ml}$ of bovine serum added to the supernatant. This procedure was repeated until there was no further 
precipitation. Absorption with hormone preparations was accomplished as with the bovine serum.

Immunological analyses. Ouchterlony plates (10) were prepared by placing $25 \mathrm{ml}$ of 0.7 per cent agar in

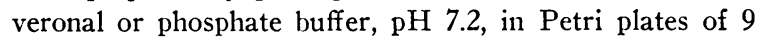
$\mathrm{cm}$ diameter. Wells were so cut as to permit the selected sera and antigens to be placed in the desired relation to one another. The wells were then filled, the dishes stored at $4^{\circ} \mathrm{C}$, and inspection made daily.

Immunoelectrophoretic analyses were performed according to the technique of Grabar and Williams (11). The electrophoretic separation of the antigen solutions and the subsequent precipitin reactions were carried out in a 1 per cent agar gel containing veronal buffer, $\mathrm{pH} 8.6$, ionic strength of 0.025 .

Bioassay for TSH activity following electrophoresis in agar. In order to establish the relationship of the immune precipitates to biologically active $\mathrm{TSH}$, duplicate electrophoretic separations were performed on standard microscope slides $(25 \times 75 \mathrm{~mm})$ coated with buffered agar (veronal, $\mathrm{pH}$ 8.2). The central antigen wells of these slides were filled with $0.015 \mathrm{ml}$ of Armour TSH (0.15 IU per $0.015 \mathrm{ml}$ ) and electrophoretic separation was carried out at a potential gradient of $10 \mathrm{v}$ per $\mathrm{cm}$ for a period of 2 hours. Following electrophoresis, a trough for antiserum was cut in the agar of one slide, parallel to the axis of electrophoretic migration, and this trough was filled with absorbed anti-TSH antiserum $\left(\mathrm{C}_{1}\right)$. Both slides were placed in a moist chamber at $4^{\circ} \mathrm{C}$ for 24 hours at which time a precipitation arc was visible on the slide containing antiserum. Strips of agar with a volume of 0.02 to $0.04 \mathrm{ml}$ were then cut perpendicularly to the electrophoretic axis from four sites, two on the cathodal side and two on the anodal side of the antigen well at distances of 2 to 3 and 4 to $5 \mathrm{~mm}$ from the well. These four strips of agar were triturated in $0.5 \mathrm{ml}$ of physiological saline and the suspension solution injected into mice for bioassay of TSH activity as described below. In a second experiment, the identical procedure was followed except that the agar strips were removed from the slide without antiserum immediately after electrophoresis, and the four sites were located at distances of 4 to 5 and 12 to $13 \mathrm{~mm}$ from the antigen well.

Bioassay methods: Tests for ncutralizing actizity of the anti-TSH antisera. Bioassay for thyrotropic activity was conducted by two methods. The initial assays were performed with the cooperation of Dr. Frederic Agate, Department of Anatomy. Rats were hypophysectomized and 10 days later received daily subcutaneous injections of the test preparations for a period of a week. The thyroids were then excised, weighed, and fixed in Bouin's solution. Cell height was measured according to standard technic. A minimum of 200 cells was counted per gland.

Later, assays were performed by the method of McKenzie (12), with minor modifications (13). Female Swiss mice, $15 \mathrm{~g}$ in weight, were fed Ken-L Bisket ration for 1 week. After this initial period, the diet was supplemented with 0.12 per cent crude thyroid, and the ani- mals were injected intraperitoneally with $8 \mu \mathrm{c} \mathrm{I}^{131}$ and subcutancously with $10 \mathrm{mg}$ of sodium thyroxine. On the fifth day after $I^{131}$ and thyroxine administration, control blood samples were obtained and the test materials were injected intravenously. Two hours after injection of the test materials, blood samples were again obtained and radioactivity measured in a well-type scintillation counter with an average background count of $192 \mathrm{cpm}$. Groups of 4 mice were used for each test point.

Testing of the antisera for antithyrotropic activity was accomplished by one of two procedures. In one, the antiserum, or the globulin fraction of the antiserum (14), was mixed with the thyrotropin preparation, placed at $4^{\circ}$ $\mathrm{C}$ overnight, and then injected without centrifugation the following morning. In the second procedure the antiserum was injected subcutaneously at 16 hours, and again at 1 hour, prior to the injection of the hormone on the opposite side of the body. Absorption of the antisera with bovine serum did not materially affect the ability of the antisera to neutralize TSH activity. Accordingly, absorption with bovine serum was not routinely performed in these bioassay studies.

\section{RESULTS}

Precipitins to TSH and other pituitary hormones analy'ied by the Ouchterlony technic. Antisera to all three TSH preparations were found to contain precipitins to bovine serum proteins and yielded one to four bands when tested in the Ouchterlony system. This is illustrated in Figure 1 for two of the antisera to Armour TSH and it is evident that several of the bands of precipitation produced against the homologous TSH preparation are continuous with bands of precipitation produced against bovine serum. Some of the precipitin bands between the antisera and TSH, however, are apparently specific for TSH antigens. These bands are seen near the antibody wells or as spurs (see arrows, Figure 1). Antiserum to Armour TSH after absorption with bovine serum still retains antibody to TSH antigens as shown in Figure 2. Three lines of precipitation are evickent between Armour TSH and these two absorbed antisera, whereas all of the precipitins to bovine serum proteins have been removed. The results of the Ouchterlony analyses of several absorbed antisera are summarized in Table I. As noted in this table, antisera to Armour TSH produced two or three lines of precipitation with Armour TSH, two lines with Condliffe TSH, and one or two lines with Pierce TSH preparations. Antisera to Condliffe TSH generally showed two bands of precipitation with the homologous antigen and 


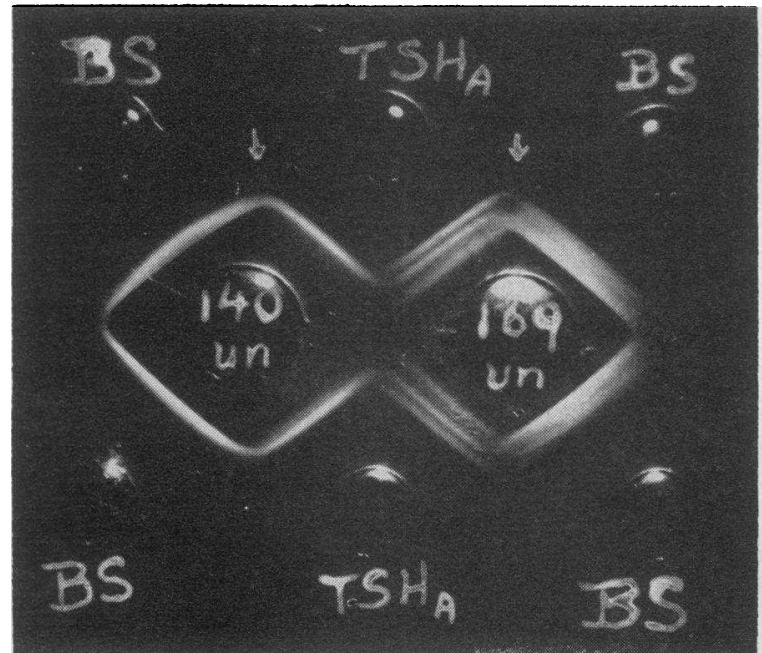

Fig. 1. Ouchterlony gel diffusion analysis of the PRECIPITIN REACTIONS BETWEEN BOVINE SERUM (BS) AND ARMOUR THYROID-STIMULATING HORMONE $\left(\mathrm{TSH}_{\Delta}\right)$ AND Two anti-Armour TSH antisera, Nos. 140 and 169, PRIOR TO ABSORPTION OF THESE ANTISERA WITH BOVINE SERUM. Bands of precipitation produced against $\mathrm{TSH}_{\Delta}$ are continuous with those against bovine serum. An inner band of precipitation and spurs at the site of the arrows (the latter not visible now, following reproduction) are specific for TSH.

with Armour TSH, and one or two bands of precipitation with Pierce TSH. Antisera to Pierce TSH showed one or two bands of precipitation against the homologous antigen and usually only

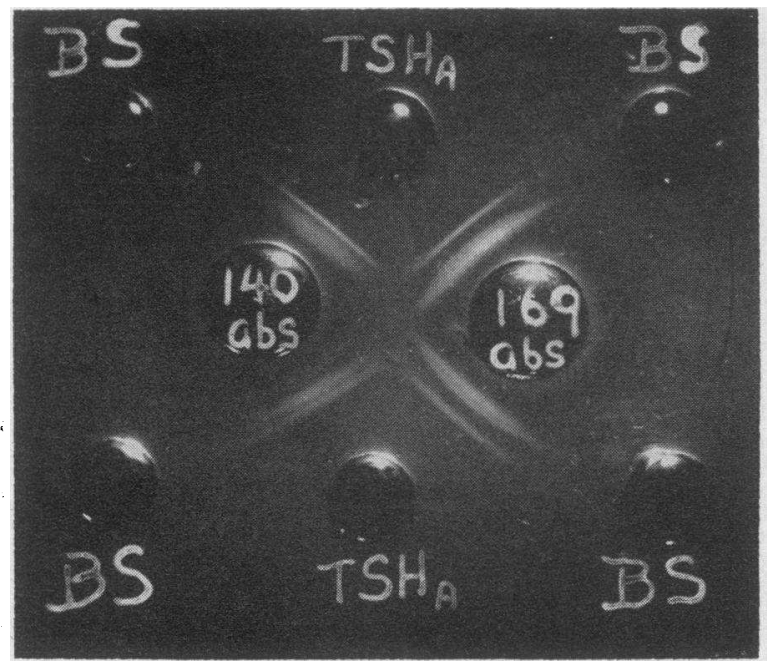

Fig. 2. Same antisera illustrated in Figure I, afTER ABSORPTION WITH BOVINE SERUM; ONLY THREE BANDS OF PRECIPITATION TO TSH REMAIN. one band when tested with the other two thyrotropins.

Anti-TSH antisera were tested for precipitin reactions with several other hormones of pituitary origin, and these results are presented in Table II. Two preparations of ovine luteinizing hormone (LH) produced precipitation with anti-Armour and anti-Condliffe TSH sera. Figure 3 illustrates the reactions between an anti-Condliffe TSH anti-

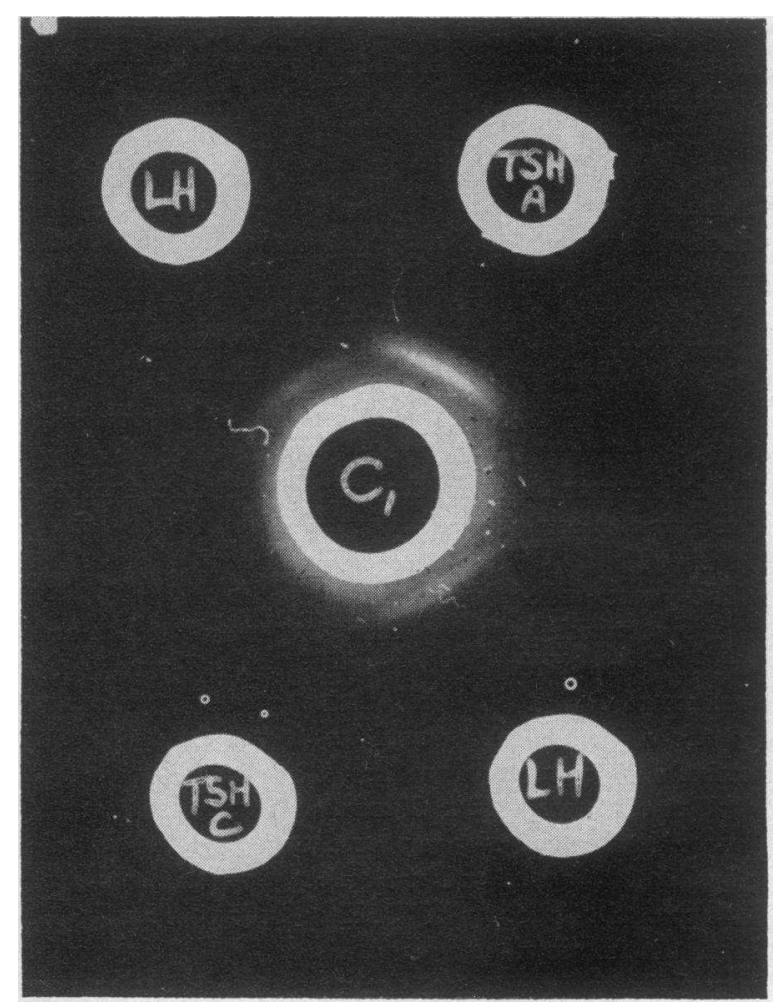

Fig. 3. Antiserum to Condliffe TSH $\left(\mathrm{C}_{1}\right)$ in center well; Condliffe TSH, Armour TSH and WilHELMI LUTEINIZING HORMONE (LH) IN OUTER WELLS. There is a line of precipitation between the antiserum and the luteinizing hormone continuous with a fine band of precipitation to the $\mathrm{TSH}$ preparations.

serum $\left(\mathrm{C}_{1}\right)$ and two preparations of TSH and $\mathrm{LH}$, respectively. The inner line of precipitation produced by the TSH preparations appears to blend with the band produced by $\mathrm{LH}$, whereas the outer band is apparently specific for a TSH antigen. Figure 4 shows that the $\mathrm{C}_{1}$ antiserum to Condliffe TSH after absorption with $\mathrm{LH}$ still retains a strong precipitin to the TSH antigen and further, as shown in Figure 5, this antigen is common to all three TSH preparations. 
TABLE I

Bovine serum absorbed antisera to thyroid-stimulating hormone (TSH) tested by the Ouchterlony technic against homologous and heterologous TSH preparations

\begin{tabular}{|c|c|c|c|c|c|c|}
\hline \multirow[b]{2}{*}{ Antisera to TSH of } & \multirow[b]{2}{*}{ Hormone } & \multicolumn{3}{|c|}{ Test hormone preparation } & \multirow{2}{*}{$\begin{array}{l}\text { Absorbed } \\
\text { with } \\
\text { bovine } \\
\text { serum } \\
\text { and }\end{array}$} & \multirow{2}{*}{$\begin{array}{c}\text { Number of } \\
\text { precipitin } \\
\text { bands in } \\
\text { Ouchterlony } \\
\text { plate* }\end{array}$} \\
\hline & & Source & $\begin{array}{l}\text { TSH content } \\
\text { (IU /mg) }\end{array}$ & LH content & & \\
\hline Armour & TSH & Armour & 1 & ++++ & & 2 or 3 \\
\hline Armour & TSH & Condliffe & 25 & $? 0$ & & 2 \\
\hline Armour & TSH & Pierce & 25 & $? 0$ & & 1 or 2 \\
\hline Condliffe & TSH & Armour & 1 & ++++ & & 2 \\
\hline Condliffe & TSH & Condliffe & 25 & see above & & 2 \\
\hline Condliffe & TSH & Pierce & 25 & see above & & 1 or 2 \\
\hline Pierce & TSH & Armour & 1 & ++++ & & 1 \\
\hline Pierce & TSH & Condliffe & 25 & see above & & 1 \\
\hline Pierce & TSH & Pierce & 25 & see above & & 1 or 2 \\
\hline Armour or Condliffe & $\mathrm{TSH}$ & $\begin{array}{l}\text { Armour, Condliffe } \\
\text { or Pierce }\end{array}$ & see above & see above & LH & 1 or 2 bands \\
\hline $\begin{array}{l}\text { Armour or Condliffe } \\
\text { or Pierce }\end{array}$ & TSH & $\begin{array}{l}\text { Armour, Condliffe } \\
\text { or Pierce }\end{array}$ & see above & see above & TSH & 0 \\
\hline
\end{tabular}

* Antisera undiluted; solutions of test TSH antigens contained 0.5 or $1.0 \mathrm{IU}$.

TABLE II

Bovine serum absorbed antisera to TSH* tested by the Ouchterlony technic against hormone other than TSH

\begin{tabular}{|c|c|c|c|c|c|}
\hline \multirow[b]{2}{*}{ Hormone } & \multicolumn{3}{|c|}{ Test hormone preparation } & \multirow{2}{*}{$\begin{array}{l}\text { Absorbed } \\
\text { with } \\
\text { bovine } \\
\text { serum } \\
\text { and }\end{array}$} & \multirow{2}{*}{$\begin{array}{c}\text { Bands in } \\
\text { Ouchterlony } \\
\text { plate† }\end{array}$} \\
\hline & Source & $\begin{array}{c}\text { TSH content } \\
(\mathrm{IU} / \mathrm{mg})\end{array}$ & LH content & & \\
\hline LH (ovine) & Wilhelmi & 0.1 & ++++ & & 1 or 2 \\
\hline LH (ovine) & McShan & & +++ & & 1 or 2 \\
\hline LH (ovine) & Wilhelmi & 0.1 & ++++ & LH & 0 \\
\hline LH (ovine) & McShan & & ++++ & LH & 0 \\
\hline G.H. (bovine) & $\mathrm{NIH}$ & 0.008 & \pm & & 1 \\
\hline G.H. (ovine) & Wilhelmi & 0 & \pm & & 2 \\
\hline $\begin{array}{l}\text { G.H. (bovine } \\
\text { or ovine) }\end{array}$ & $\begin{array}{l}\text { NIH or } \\
\text { Vilhelmi }\end{array}$ & see above & see above & LH & 0 \\
\hline G.H. (human) & Raben & 0 & 0 & & 0 \\
\hline G.H. (human) & Wilhelmi & 0 & 0 & & 0 \\
\hline G.H. (porcine) & Wilhelmi & 0 & 0 & & 0 \\
\hline G.H. (simian) & Wilhelmi & + & + & & 0 \\
\hline $\begin{array}{l}\text { Urine gonado- } \\
\text { tropin (human) }\end{array}$ & Albert & 0 & + & & 0 \\
\hline Prolactin & $\mathrm{NIH}$ & 0.004 & 0 & & 0 \\
\hline Pitressin & Parke, Davis & 0 & 0 & & 0 \\
\hline Pitocin & Parke, Davis & 0 & 0 & & 0 \\
\hline ACTH & Armour & 0 & 0 & & 0 \\
\hline
\end{tabular}

* Antisera to TSH to Armour or Condliffe.

$\dagger$ Antisera undiluted. 


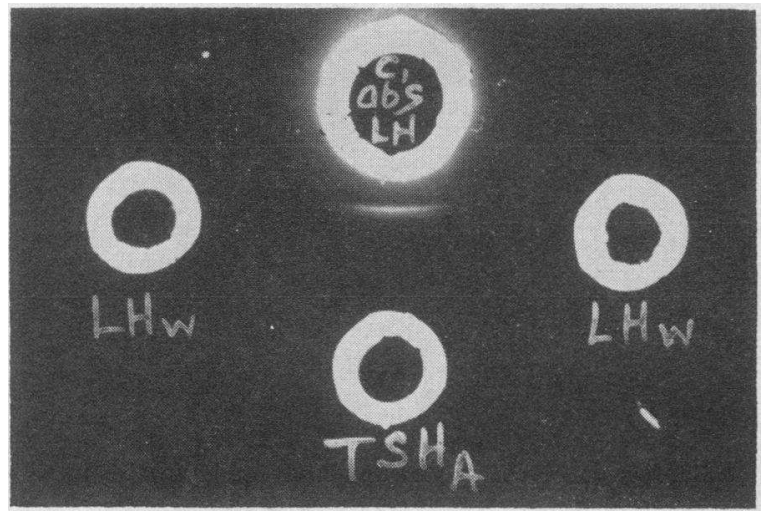

Fig. 4. Demonstration of the persistence of the REACTIONS BETWEEN TSH AND ANTI-TSH ANTISERUM AFTER ABSORPTION OF THIS ANTISERUM WITH LUTEINIZING HORMONE. Antiserum to Condliffe TSH absorbed with luteinizing hormone $\left(\mathrm{C}_{1}\right.$ abs $\left.\mathrm{LH}\right)$ in top well; luteinizing hormone ( $\mathrm{LHw})$.

Among the other pituitary hormones tested (Table II) only two preparations of growth hormone gave a band of precipitation with the anti$\mathrm{TSH}$ antisera and this precipitation was eliminated in both instances by absorption with $\mathrm{LH}$, indicating contamination of these $\mathrm{GH}$ preparations with LH.

Immunoelectrophoretic analysis. For purposes of estimating the electrophoretic mobilities of the antigens, a reference sample of normal human serum was run on each plate, and reacted with an equine antiserum ${ }^{1}$ to pooled normal human serum. These mobility references are illustrated in Figures 8 and 9. It should be noted that, as a result of elctroendosmosis and the flow of buffer toward the cathode during the period of electrophoresis, $\gamma$-globulin and part of the $\beta$-globulin fraction are displaced to the cathodal side of the antigen well, although their net electrophoretic migrations are in an anodal direction under the conditions of $\mathrm{pH} 8.6$ employed.

The major serum protein constituents present as impurities in the Condliffe and Armour TSH preparations are identifiable by immunoelectrophoretic analysis. In Figure $6 \mathrm{~A}$ it is seen that a very strong precipitin arc having the characteristic polydispersed electrophoretic distribution of $\gamma$-globulin is obtained when anti-Condliffe TSH antiserum is reacted against bovine serum. Fig-

1 Equine antihuman serum no. 511, Institut Pasteur, Paris.

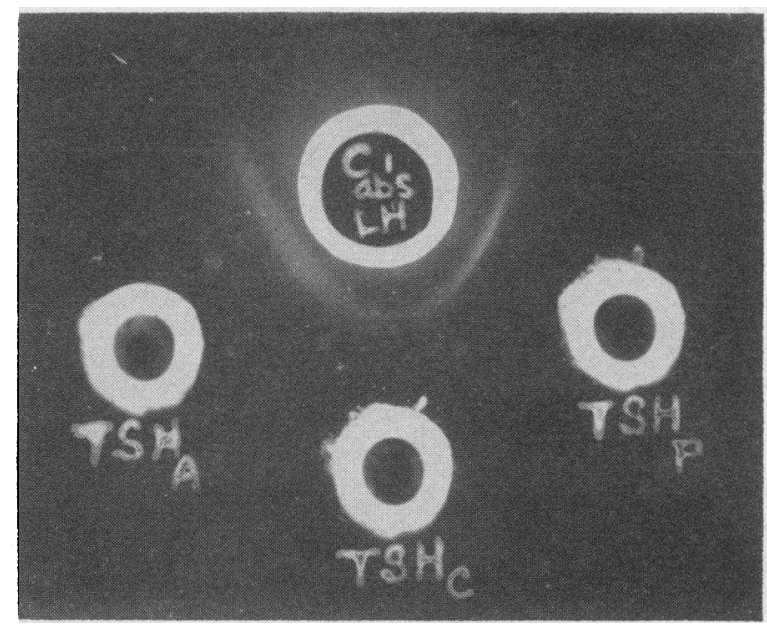

Fig. 5. Demonstration of a Reaction of identity aMONG tiree TSH pREParations (ARMOUR, Coni)liffe and Pirkce) produced by $\mathrm{C}_{1}$ abs LH antiserum.

ure $6 \mathrm{~B}$ shows that the major serum protein present in the Armour TSH preparation is albumin. The Armour TSH preparation also contains some $\gamma$-globulin, although this is not well seen in Figure $6 \mathrm{~B}$. These arcs were eliminated by absorption of these antisera with bovine serum. The reactions of Armour TSH with unabsorbed and absorbed anti-Armour TSH antiserum are shown in Figure 6C. It is seen that the absorption with bovine serum eliminates the precipitin arcs in the albumin and gamma regions, leaving a single arc in the $\alpha-2$ mobility range.

Figure 7A shows that the anti-Condliffe TSH antiserum, after absorption with bovine serum, produces a single precipitin arc in the fast beta mobility range when reacted with its homologous antigen but, significantly, this same absorbed antiCondliffe TSH antiserum, when reacted with the Armour TSH preparation, produces three, or possibly four, precipitin arcs covering a broad range of mobility from the slow beta to the fast alpha region (Figure 7B). The details of this reaction between the absorbed anti-Condliffe TSH antiserum and Armour TSH are better illustrated in Figure 8. It is apparent that all of the arcs are immunologically interrelated, as evidenced both by fusion of their extremities and by their similar electrophoretic distributions and geometric shapes. Thus, the inner alpha arc, designated $\alpha^{\prime}$, has a long cathodal extension traversing into the beta region. The outer alpha arc, designated $\alpha^{\prime \prime}$, 


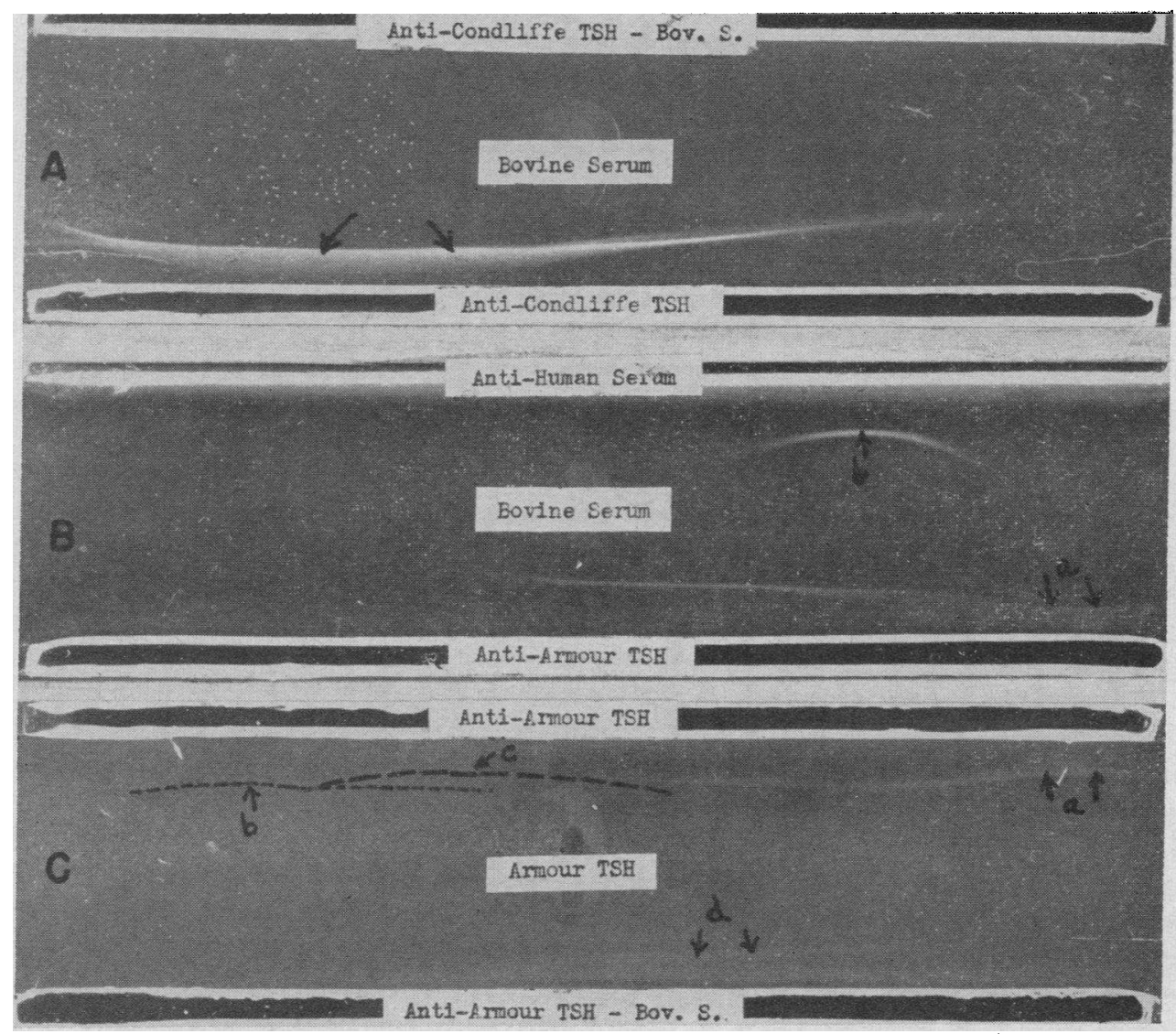

FIG. 6. IMMUNOELECTROPHORETIC ANALYSES OF THE PRECIFITIN REACTIONS OF THE ANTI-TSH ANTISERA PRIOR TO AND FOLLOWING ABSORPTION WITH BOVINE SERUM. In all of these analyses, the direction of electrophoretic migration is from left to right (anode on right); the cathodal displacement of antigens (to the left of the antigen wells) is the result of electroendosmotic flow.

A. Reaction of bovine Serum with UNABSORbed anti-Condliffe TSH (LOWER TROUgh) AND ABSORBED ANTi-CoNDliffe TSH ANTISERA (UPPER tROUGH). The long, polydispersed precipitin arc (arrows) produced by the unabsorbed antiserum has the characteristic distribution and mobility of $\gamma$-globulin.

B. Reaction of bovine serum with unabsorbed anti-Armour TSH antiserum (Lower

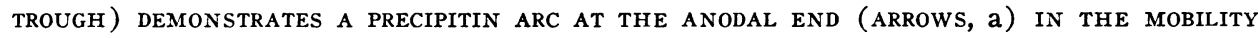
RANGE OF ALBUMIN. The long cathodal tail of this arc may represent the effect of partial denaturation. A bovine serum protein with the mobility of an $\alpha-2$ globulin (arrow b) is seen to cross react with an antiserum to normal human serum (upper trough).

C. Reaction of Armour TSH with unabsorbed (UPPER trough) and absorbed (lower TROUGH) ANTI-ARMOUR TSH ANTISERUM. With the unabsorbed antiserum, the arc considered to be that of albumin (arrows a) is again seen, as in B; a faint arc in the gamma mobility range (dotted line, arrow b), and an arc of beta mobility (dashed line, arrow c) are also demonstrated. After absorption with bovine serum, only one arc, of $\alpha-2$ mobility (arrows, d) remains. (The straight line near the bottom trough is an artifact.)

also can be interpreted as either having a long cathodal extension, or alternately as fusing with another precipitin arc of beta mobility which is designated $\beta^{\prime}$. Finally, the anodal end of the outer beta arc, $\beta^{\prime \prime}$, partially fuses with outer alpha arc, $\alpha^{\prime \prime}$. The possible interpretations of these findings are discussed below.

Immunoelectrophoretic analysis of the reaction of luteinizing hormone with anti-TSH-antiserum. As noted above, a preparation of $\mathrm{LH}$ of ovine ori- 


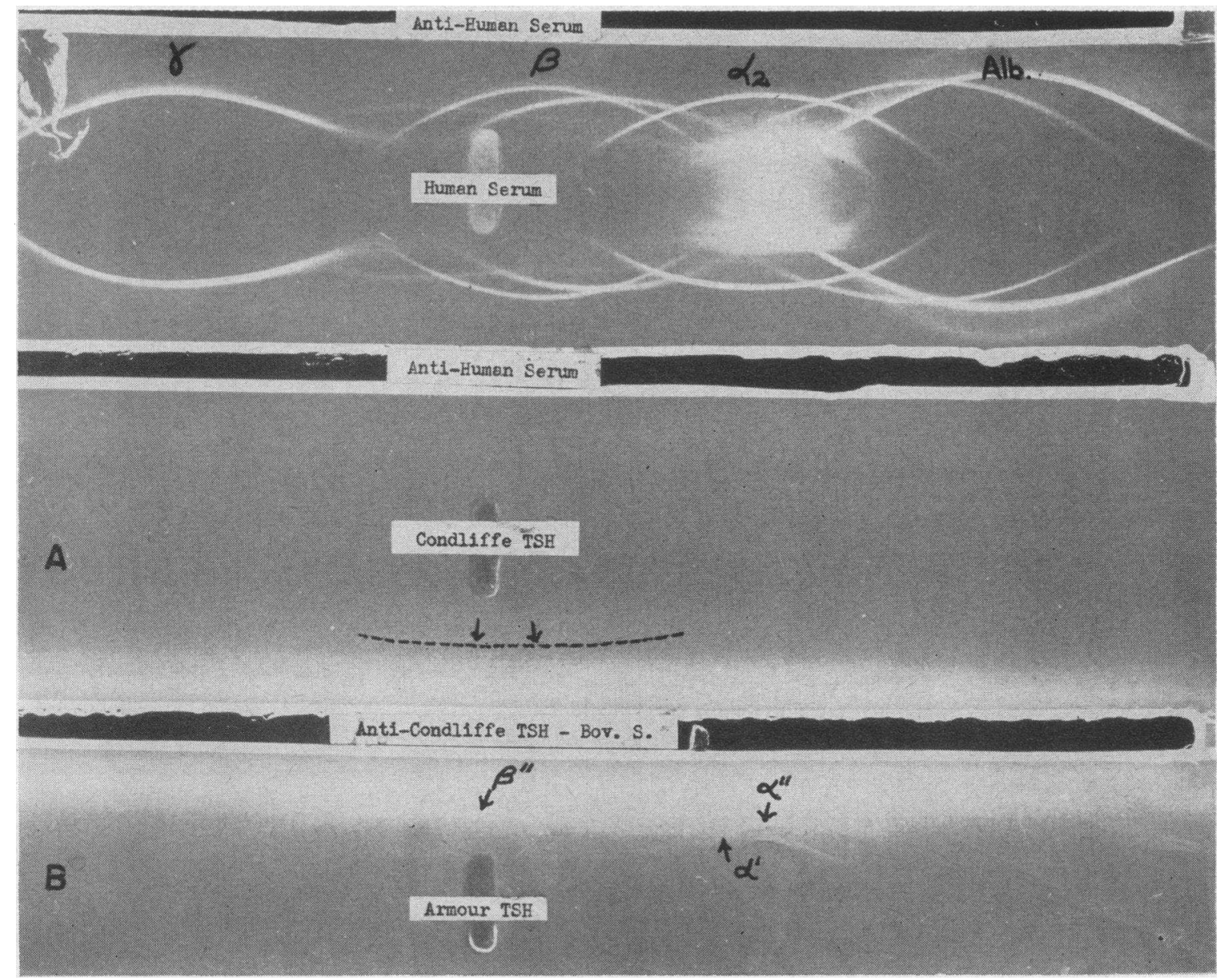

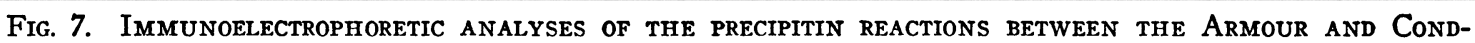
LIFFE TSH PREPARATIONS AND AN ANTI-CONDLIFFE TSH ANTISERUM ABSORBED With BOvine SERUM. For purposes of estimating electrophoretic mobilities, an analysis of human serum reacted with horse antihuman serum is shown in the top section.

A. Reaction of Condliffe TSH with anti-Condliffe TSH antiserum absorbed with bovine serum (Lower trough) DEMONSTRATING A SINGLe ARC OF BETA MOBILITy (DOTTED LiNe, ARROWS).

B. Reaction of Armour TSH with anti-Condliffe TSH antiserum absorbed with bovine serum (UPPER trough) demonstrating a long precipitin arc with apparently two separate maxima ( $\alpha^{\prime \prime}$ ANd $\beta^{\prime \prime}$ ), AND ANOTHER ARC OF ALPHA MOBILITY $\left(\alpha^{\prime}\right)$. These arcs are better visualized in Figure 8.

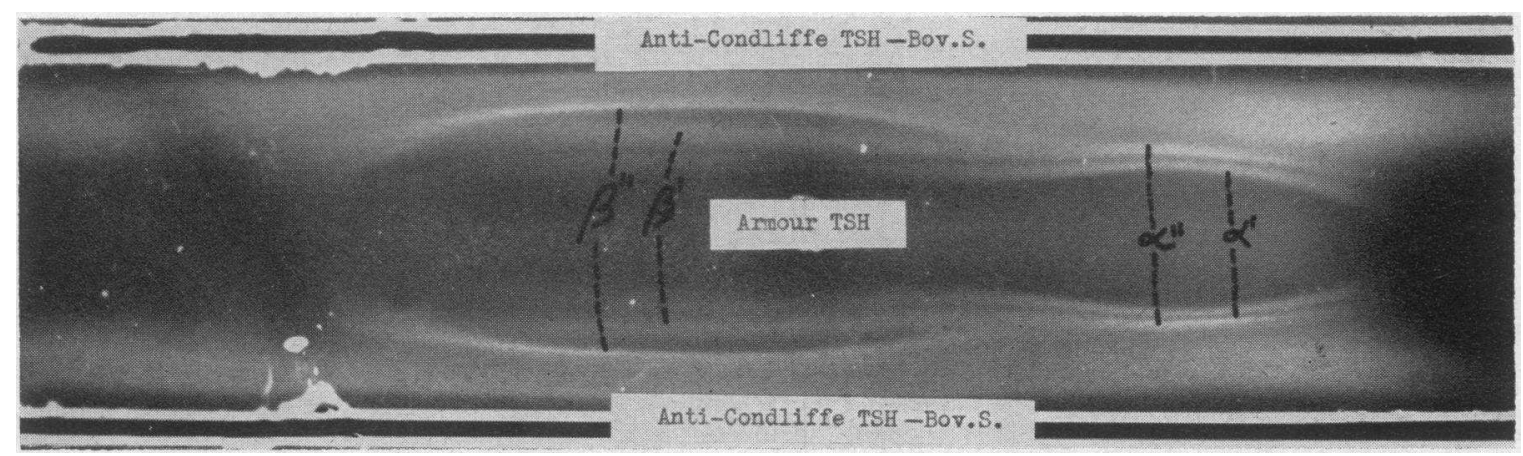

Fig. 8. Reaction of Armour TSH with anti-Condliffe TSH Antiserum absorbed with bovine Serum (Both TOP AND вотtom TROUGHS). See text for discussion of this figure. 


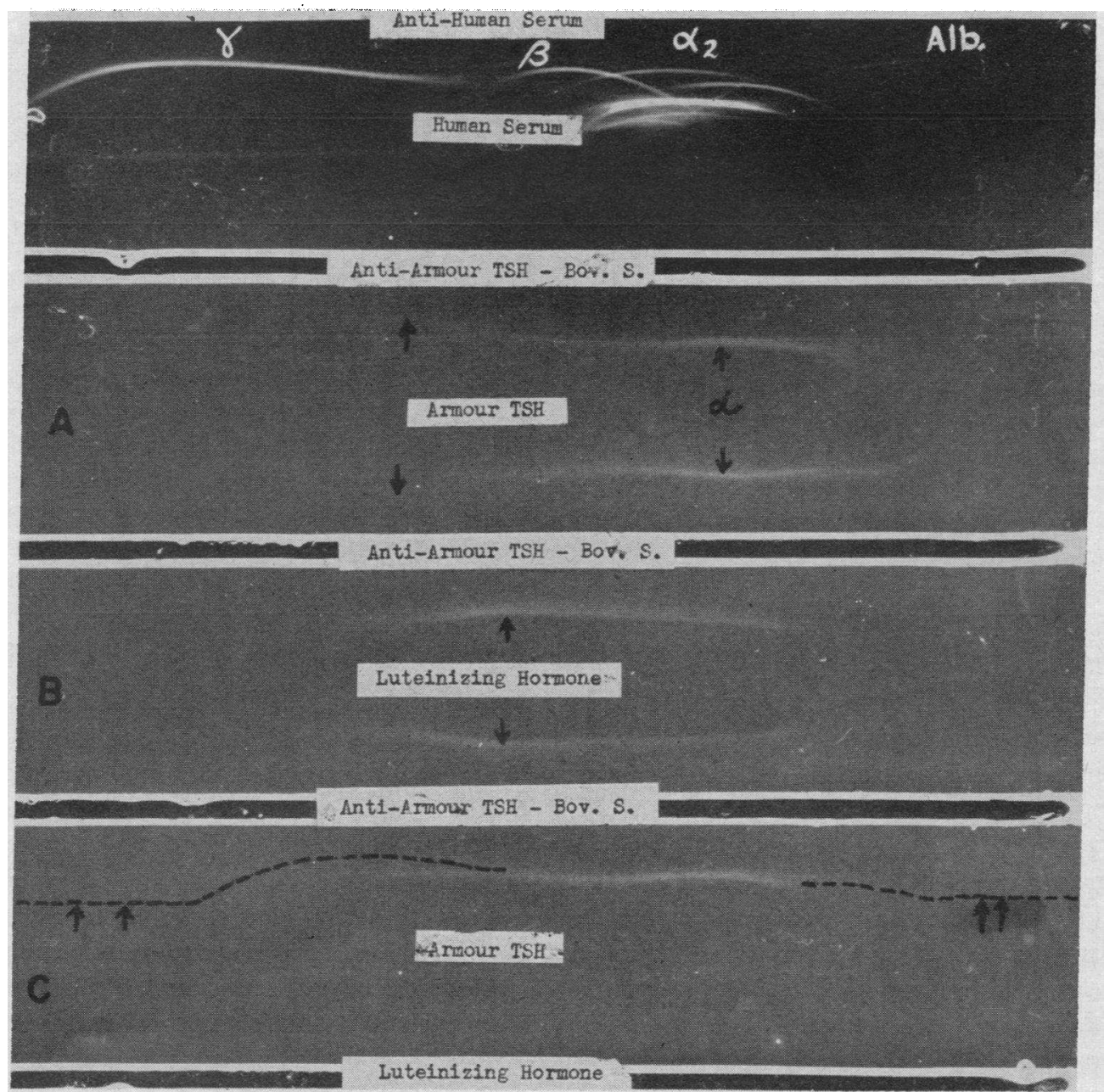

Fig. 9. IMMUNOELECTROPHORETIC ANALYSES OF THE CROSS REACTION BETWEEN OVINE LUTEINIZING HORMONE AND ANTI-ARMOUR TSH ANTISERUM ABSORBED WITH BOVINE SERUM. The upper section shows the reaction of human serum with horse antihuman serum as a mobility reference.

A. Reaction of Armour TSH with anti-Armour TSH antiserum absorbed with bovine SERUM (UPPER AND LOWER TROUGHS). A long precipitin arc extending from the fast alpha to the slow beta mobility range is seen; the region of maximal precipitation is in the alpha mobility range.

B. Reaction of LUteinizing hormone with anti-Armour TSH antiserum absorbed With BOVINE SERUM (UPPER AND LOWER TROUGHS). A long precipitin arc is again seen, but the maximal precipitation is in the beta mobility range.

C. Analysis of the interRelationships of ARmour TSH and luteinizing hormone, usING A THREe-REACTANT System. The Armour TSH was electrophoresed. The antiserum was placed in the upper trough, and the luteinizing hormone in the lower trough. The straight lines of precipitation (dashed lines, arrows) at the anodal and cathodal ends of the agar represent the reaction between the luteinizing hormone and the anti-TSH antiserum. These lines partially fuse with the anodal and cathodal ends of the arc produced by the reaction between the Armour $\mathrm{TSH}$ and the antiserum.

gin (Wilhelmi LH) cross reacts with anti-TSH antiserum. The immunoelectrophoretic analysis of this reaction is shown in Figure 9. An antiArmour TSH antiserum, different from that shown in previous patterns, was employed in this study. When this antiserum was reacted with its homologous antigen (Armour TSH), a strong precipitin arc of alpha mobility and a much weaker 
TABLE III

Distribution of TSH activity following electrophoresis in agar; assays performed in I ${ }^{131}$-labeled, thyroid-suppressed mice

\begin{tabular}{|c|c|c|c|}
\hline Experiment & $\begin{array}{l}\text { No. of } \\
\text { mice }\end{array}$ & Media & $\begin{array}{l}\% \text { Control } \\
\text { radioactivity } \\
\pm \text { SD at } \\
2 \text { hours }\end{array}$ \\
\hline $\begin{array}{l}\text { A } \\
\text { Strips removed } \\
\text { from the agar } \\
\text { after } 18 \text { hours } \\
\text { at } 4^{\circ} \mathrm{C}\end{array}$ & $\begin{array}{l}4 \\
4 \\
4 \\
4 \\
4 \\
4 \\
4\end{array}$ & $\begin{array}{l}\text { Control: saline } 0.2 \mathrm{cc} \\
\text { Control: Armour TSH } 0.1 \mathrm{~m} \mu \\
\text { Control: buffered agar } \\
\text { Anode agar, } 4-5 \mathrm{~mm} \text { from well } \\
\text { Anode agar, } 2-3 \mathrm{~mm} \text { from well } \\
\text { Cathode agar } 2-3 \mathrm{~mm} \text { from well } \\
\text { Cathode agar, } 4-5 \mathrm{~mm} \text { from well }\end{array}$ & $\begin{array}{r}95 \pm 20 \\
162 \pm 17 \\
88 \pm 12 \\
203 \pm 67 \\
250 \pm 47 \\
532 \pm 44^{*} \\
559 \pm 122^{*}\end{array}$ \\
\hline $\begin{array}{l}\text { B } \\
\text { Strips removed } \\
\text { from the agar } \\
\text { immediately } \\
\text { following } \\
\text { electrophoresis }\end{array}$ & $\begin{array}{l}4 \\
4 \\
4 \\
4 \\
4 \\
4\end{array}$ & $\begin{array}{l}\text { Control: saline } 0.2 \mathrm{cc} \\
\text { Control: Armour TSH } 0.1 \mathrm{~m} \mu \\
\text { Anode agar, } 12-13 \mathrm{~mm} \text { from well } \\
\text { Anode agar, 4-5 mm from well } \\
\text { Cathode agar, 4-5 mm from well } \\
\text { Cathode agar, } 12-13 \mathrm{~mm} \text { from well } \\
\text {. }\end{array}$ & $\begin{array}{r}91 \pm 11 \\
153 \pm \\
81 \pm \\
84 \pm \\
542 \pm 98^{*} \\
144 \pm 23^{*}\end{array}$ \\
\hline
\end{tabular}

${ }^{*} \mathrm{p}<0.001$.

beta arc (or possibly a beta extension of the alpha arc) was obtained (Figure 9A). When reacted with ovine $\mathrm{LH}$, this antiserum yielded a long arc extending across the beta and alpha regions, but, in contrast to the homologous system, the precipitation maximum of this $\mathrm{LH}$ arc was in the beta region (Figure 9B). In an attempt to elucidate the interrelationship of the TSH and $\mathrm{LH}$ precipitin arcs, a modified immunoelectrophoretic procedure (15) was utilized whereby the eletrophoretically separated TSH fraction was simultaneously reacted with both the anti-TSH antiserum and the LH (Figure 9C). In this analysis, the LH was permitted to diffuse from a trough in the agar on the side of the antigen reservoir opposite the antiserum trough. This reaction is ilustrated in Figure 9C. It is seen that the precipitin reaction between $\mathrm{LH}$ and the anti-TSH antiserum is in the form of a straight line, and that the cathodal end of this line partially fuses with the anodal end of the alpha arc of TSH. This establishes a partial immunological relationship between $\mathrm{TSH}$ and $\mathrm{LH}$, but not complete identity. The thesis that these proteins are not identical is further supported by the differences in their electrophoretic maxima.

Bioassay for TSH activity following electrophoresis in buffered agar. Two bioassay experiments for TSH activity were performed on agar strips removed from slides following electrophoresis. The results of these experiments are shown in Table III. In the first experiment (A), the slides were kept overnight at $4^{\circ} \mathrm{C}$ before removal of the agar strips; in the second experiment (B), the agar strips were removed immediately following electrophoresis.

In Experiment A, TSH activity was demonstrable on both the anodal and the cathodal side of the antigen well, corresponding to the distribution of immune precipitation in the control slide developed with anti-TSH antiserum. The activity

TABLE IV

Inhibition of TSH (Armour) activity in the hypophysectomized rat by rabbit antithyrotropin serum

\begin{tabular}{|c|c|c|c|c|c|}
\hline Animals & $\underset{\substack{\text { Amount of } \\
\text { TSHour }}}{ }$ & $\begin{array}{l}\text { Amount } \\
\text { of serum }\end{array}$ & $\begin{array}{c}\text { Nature of rabbit } \\
\text { serum }\end{array}$ & $\begin{array}{l}\text { TSH and/or serum } \\
\text { administration }\end{array}$ & $\begin{array}{c}\text { Average } \\
\text { thyroid cell } \\
\text { height }\end{array}$ \\
\hline $\begin{array}{c}\text { No. } \\
6\end{array}$ & $\begin{array}{c}I U / d a y \\
\text { none }\end{array}$ & $\begin{array}{l}m l / d a y \\
\text { none }\end{array}$ & & $\begin{array}{l}\text { No. of days } \\
\text { hypophysectomized } \\
\text { untreated controls }\end{array}$ & $\begin{array}{c}\mu \pm S D \\
4.3 \pm 1.3\end{array}$ \\
\hline $\begin{array}{l}3 \\
6 \\
3 \\
3\end{array}$ & $\begin{array}{l}\text { none } \\
5 \\
5 \\
5\end{array}$ & $\begin{array}{c}1.0 \\
\text { none } \\
0.5 \\
0.5\end{array}$ & $\begin{array}{c}\text { normal } \\
\text { normal } \\
\text { anti-Armour TSH }\end{array}$ & $\begin{array}{l}7 \\
7 \\
7 \\
7\end{array}$ & $\begin{array}{l}4.5 \pm 1.3 \\
7.7 \pm 1.6 \\
8.2 \pm 1.7 \\
5.0 \pm 1.3\end{array}$ \\
\hline
\end{tabular}


TABLE $V$

Inhibition of TSH activity in the mouse by rabbit antithyrotropin serum; assays performed in $I^{131}$-labeled, thyroid-suppressed mice

\begin{tabular}{|c|c|c|c|c|}
\hline Exp't. no. & $\begin{array}{c}\text { No. of } \\
\text { animals }\end{array}$ & TSH preparation & $\begin{array}{l}\text { Antiserum or globulin } \\
\text { fraction }\end{array}$ & $\begin{array}{l}\% \text { Control } \\
\text { radioactivity } \\
\pm \mathrm{SD} \text { at } \\
2 \text { hours }\end{array}$ \\
\hline \multirow[t]{3}{*}{144} & 4 & None (saline) & None & $123 \pm 16$ \\
\hline & 4 & $\begin{array}{l}\text { Bovine TSH } \\
\quad \text { (Armour) } 1 \mathrm{~m} \mu\end{array}$ & $\begin{array}{l}10 \mathrm{mg} \text { normal rab. } \\
\text { glob. }(=0.5 \mathrm{ml})\end{array}$ & $310 \pm 48$ \\
\hline & 4 & $\begin{array}{l}\text { Bovine TSH } \\
\quad \text { (Armour) } 1 \mathrm{~m} \mu\end{array}$ & $\begin{array}{l}10 \mathrm{mg} \text { anti- } \\
\text { Arnour glob. } \\
(=0.5 \mathrm{ml})\end{array}$ & $136 \pm 4^{*}$ \\
\hline \multirow[t]{4}{*}{164} & 4 & None (saline) & None & $126=27$ \\
\hline & 4 & $\begin{array}{l}\text { Bovine TSH (Cond- } \\
\text { liffe) } 1 \mathrm{~m} \mu\end{array}$ & None & $230 \pm 53$ \\
\hline & 4 & $\begin{array}{l}\text { Bovine TSH (Cond- } \\
\text { liffe) } 1 \mathrm{~m} \mu\end{array}$ & $\begin{array}{l}10 \mathrm{mg} \text { normal rab. } \\
\text { glob. }(=1.0 \mathrm{ml})\end{array}$ & $217 \pm 60$ \\
\hline & 4 & $\begin{array}{l}\text { Bovine TSH (Cond- } \\
\text { liffe) } 1 \mathrm{~m} \mu\end{array}$ & $\begin{array}{l}12 \mathrm{mg} \text { anti- } \\
\text { Armour glob. } \\
(=1.0 \mathrm{ml})\end{array}$ & $133 \pm 19^{*}$ \\
\hline \multirow[t]{3}{*}{214} & 4 & None (saline) & None & $151 \pm 26$ \\
\hline & 4 & $\begin{array}{l}\text { Bovine TSH (Pierce) } \\
\quad 1 \mathrm{~m} \mu\end{array}$ & None & $174 \pm 25$ \\
\hline & 4 & $\begin{array}{l}\text { Bovine TSH (Pierce) } \\
\quad 1 \mathrm{~m} \mu\end{array}$ & $\begin{array}{l}7.7 \mathrm{mg} \text { anti- } \\
\text { Pierce glob. } \\
(1.0 \mathrm{ml})\end{array}$ & $104 \pm 12^{*}$ \\
\hline \multirow[t]{3}{*}{220} & 4 & None (saline) & None & $116 \pm 52$ \\
\hline & 4 & $\begin{array}{l}\text { Bovine TSH (Pierce) } \\
\quad 1 \mathrm{~m} \mu\end{array}$ & None & $181 \pm 60$ \\
\hline & 4 & $\begin{array}{l}\text { Bovine TSH (Pierce) } \\
\qquad 1 \mathrm{~m} \mu\end{array}$ & $\begin{array}{l}3.85 \mathrm{mg} \text { anti- } \\
\text { Pierce glob. } \\
(=0.5 \mathrm{ml})\end{array}$ & $102 \pm 19^{*}$ \\
\hline \multirow[t]{4}{*}{220} & 4 & None (saline) & None & $85 \pm 10$ \\
\hline & 4 & $\begin{array}{l}\text { Mouse pit. tumor } \\
\quad \text { (Condliffe) } 0.5 \mathrm{~m} \mu\end{array}$ & None & $271 \pm 68$ \\
\hline & 4 & $\begin{array}{l}\text { Mouse pit. tumor } \\
\text { (Condliffe) } 0.5 \mathrm{~m} \mu\end{array}$ & $\begin{array}{l}0.5 \text { ml anti- } \\
\text { Armour }\end{array}$ & $106 \pm 24$ \\
\hline & 4 & $\begin{array}{l}\text { Mouse pit. tumor } \\
\text { (Condliffe) } 0.5 \mathrm{~m} \mu\end{array}$ & $\begin{array}{l}1.0 \mathrm{ml} \text { anti- } \\
\text { Armour }\end{array}$ & $110 \pm 28^{*}$ \\
\hline \multirow[t]{4}{*}{226} & 4 & None (saline) & None & $85 \pm 10$ \\
\hline & 4 & $\begin{array}{l}\text { Human TSH } \\
\quad \text { (Bakke) } 0.25 \mathrm{~m} \mu\end{array}$ & None & $204 \pm 14$ \\
\hline & 4 & $\begin{array}{l}\text { Human TSH } \\
\text { (Bakke) } 0.25 \mathrm{~m} \mu\end{array}$ & $\begin{array}{l}0.25 \mathrm{ml} \text { anti- } \\
\text { Armour }\end{array}$ & $111 \pm 10^{*}$ \\
\hline & 4 & $\begin{array}{l}\text { Human TSH } \\
\quad(\text { Bakke) } 0.25 \mathrm{~m} \mu\end{array}$ & $\begin{array}{l}0.5 \mathrm{ml} \text { anti- } \\
\text { Armour }\end{array}$ & $123 \pm 24^{*}$ \\
\hline \multirow[t]{4}{*}{238 and 140} & 10 & None (saline) & None & $97 \pm 26$ \\
\hline & 4 & $\begin{array}{l}\text { Human TSH } \\
\quad \text { (Bakke) } 0.5 \mathrm{~m} \mu\end{array}$ & None & $267 \pm 133$ \\
\hline & 4 & $\begin{array}{l}\text { Human TSH } \\
\text { (Bakke) } 0.5 \mathrm{~m} \mu\end{array}$ & $\begin{array}{l}3 \mathrm{mg} \text { normal rab. } \\
\text { glob. }(=0.25 \mathrm{ml})\end{array}$ & $337 \pm 101$ \\
\hline & 4 & $\begin{array}{l}\text { Human TSH } \\
\text { (Bakke) } 0.5 \mathrm{~m} \mu\end{array}$ & $\begin{array}{l}2 \mathrm{mg} \text { anti- } \\
\text { Armour glob. } \\
(=0.1 \mathrm{ml})\end{array}$ & $113 \pm 13^{*}$ \\
\hline
\end{tabular}

$* \mathrm{p}<0.001$ 
on the cathodal side of the antigen well was considerably greater than on the anodal sicle. In Experiment $\mathrm{B}$, activity was found only on the cathodal side of the antigen well, suggesting that the activity found on the anodal side in Experiment $\mathrm{A}$ was the result, at least in part, of diffusion.

Neutralization of thyrotropin effect by antiTSH antiserum. By means of the two bioassay systems described above, it was possible to demonstrate that the anti-TSH antisera were capable of neutralizing the thyrotropic actions of both homologous and heterologous TSH preparations. Both the whole antisera and the globulin fractions thereof were effective, whereas normal rabbit serum and its globulin fraction were totally ineffective. A precise titration of the least amount of antiserum which would neutralize a given amount of TSH was not performed, but this is planned for future studies. Table IV presents the results of a bioassay in hypophysectomized rats, employing Armour TSH and anti-Armour TSH antisera. Table $\mathrm{V}$ presents the data derived from seven experiments in which antisera to Armour TSH and Pierce TSH were tested for antithyrotropic activity in mice given several different TSH preparations of bovine, human and murine origin. Significant cross reactions between the antisera to bovine TSH and the thyrotropin preparations obtained from other species are evident, but precise quantitative data were not obtained due to the lack of availability of sufficient amounts of the human and murine TSH preparations.

\section{DISCUSSION}

In 1958, Henry and Van Dyke (16) described the production and characterization of precipitating antibodies to bovine luteinizing hormone, and in 1959 Hayashida and $\mathrm{Li}$ (17) reported similar immunochemical studies of antisera to pituitary growth hormone of various species. The present report describes the results of an immunologic and biologic analysis of antisera to bovine thyrotropin preparations. Precipitating antibody was produced, and this antibody appears to be specific for bovine thyrotropic hormone. A reaction of identity as defined by the criteria of Ouchterlony (10) was obtained when the anti-TSH antiserum was tested against three different preparations of bovine TSH of varying degrees of purity.
In addlition to the precipitins to $\mathrm{TSH}$, these antisera were demonstrated to contain precipitating antibodies to various bovine serum proteins and also to LH. By the immunoelectrophoretic technic, it was possible to identify albumin and $\gamma$-globulin as the major serum protein contaminants of the Armour TSH preparation, and $\gamma$-globulin as the principal contaminant of the more highly purified TSH preparation of Condliffe. After absorption of the antisera with bovine serum, these precipitins were removed, leaving only the precipitins to TSH and to LH. Additional absorption of the anti-TSH antisera with $\mathrm{LH}$ removed the precipitins to $\mathrm{LH}$, leaving only the precipitins to TSH. Significantly, the precipitin reaction which had been observed between the anti-TSH antisera and two preparations of pituitary growth hormone, prior to the absorption of the antisera with $\mathrm{LH}$, was no longer present after absorption. This observation has been interpreted as indicating contamination of these growth hormone preparations with luteinizing hormone.

Whereas the immunoelectrophoretic analysis of the reaction between the highly purified Condliffe TSH preparation and its homologous antiserum revealed a single precipitin arc in the beta mobility range, the reaction between this same antiserum (anti-Condliffe TSH) and the Armour TSH preparation revealed a uniquely complex pattern with four precipitin arcs; two of alpha and two of beta mobility. All four of these arcs appeared to be immunologically interrelated as evidenced both by fusion of their extremities and by their similar electrophoretic distributions and geometric shapes. There would appear to be at least three possible interpretations of these immunoelectrophoretic findings. 1) There may be two immunologically related, but electrophoretically distinct proteins in the Armour TSH preparations, one of alpha and one of beta mobility, and the reduplication of the arcs may represent the effect of antigen or antibody excess as elucidated by Korngold and van Leeuwen (18). 2) There may be two distinct proteins (alpha and beta), and the reduplication of their respective arcs may be the result of partial denaturation or degradation, as detailed in the studies of Lapresle (19). 3) Each of the arcs may truly represent a separate and distinct protein constituent. It is impossible to choose among these alternatives on the basis of the present data. 
Confirmation of the fact that TSH migrates in an electrical field was obtained by the bioassay of segments of buffered agar following electrophoresis. The maximal thyrotropic activity was found in the beta mobility range and corresponded to the region of maximal immune precipitation. It should be re-emphasized that the cathodal displacement of this arc (and of the active thyrotropic hormone) is the result of electroendosmotic flow, and that an uncharged moiety would have been displaced much farther toward the cathode under these conditions of electrophoresis in agar. It is noteworthy that recent studies by Carsten and Pierce (20) of chromatographically purified preparations of TSH have demonstrated migration of TSH activity in starch gel electrophoresis over a wide $\mathrm{pH}$ range, including $\mathrm{pH} 8.6$ used in the present studies. It is not possible, however, to compare the electrophoretic mobility of a protein in agar with its mobility in the starch gel medium, since these media, per se, exert unique physical influences on the movement of proteins through them.

A partial immunologic relationship has been shown to exist between thyrotropin and $\mathrm{LH}$ but immunoelectrophoretic analysis has established that these two pituitary principles are not immunochemically identical, and non-iclentity is further supported by the observed differences in the electrophoretic maxima of the two hormones.

By two different bioassay methods, the antiTSH antisera have been shown to be capable of neutralizing the thyrotropic activity of both homologous and heterologous TSH preparations. Cross neutralization of TSH activity was demonstrated between the anti-bovine TSH antisera and TSH from mouse pituitary tumor and human pituitary sources. Thus, antisera to TSH would seem not to be as highly species specific as antisera to growth hormone (17), and this is in good correspondence with the known effectiveness of TSH from bovine and other sources in heterologous species.

It is still not established whether the precipitating antibody to beef TSH is directed to and specific for the hormonally active groupings of the TSH molecule or to some other part of the molecule. As stated previously, studies of flavianic acid preparations of TSH (4) have suggested that the biologically active part of the thyrotropin molecule may not be antigenic. If, incleed, the antibodies are directed against a physiologically inactive part of the TSH molecule, the neutralizing ability of the antisera might be explained as due to the complexing of thyrotropin by antibody, and sequestration of this complex in the reticuloendothelial system.

\section{SUMMARY}

1. Antisera to three bovine thyrotropin preparations were produced by hyperimmunization of rabbits, and these antisera were immunologically and biologically characterized.

2. Precipitating antibody, apparently specific for thyrotropin, was clemonstrated by gel diffusion technics.

3. Parallel immunoelectrophoretic analyses and bioassays for thyroid-stimulating hormone (TSH) activity of segments of agar after electrophoresis confirmed the migration of thyrotropin in an electrical field and support the conclusion that the precipitins are specific for the thyrotropic principle.

4. Luteinizing hormone was found to be immunologically related to, but not iclentical with thyrotropin.

5. By two different bioassay methods, the antiTSH antisera were shown to be capable of neutralizing the thyrotropic activity of both homologous and heterologous TSH preparations.

\section{ACKNOWLEDGMENT}

The authors wish to express their appreciation to the following investigators who were most generous in supplying hypophyseal extracts for study: Drs. Alfred E. Wilhelmi and Stanley Ellis: John L. Bakke and Peter Heidemann: Peter G. Condliffe and Robert W. Bates; John L. Pierce; Maurice Raben; and William McShan. They also wish to acknowledge the advice of Drs. Elvin Kabat and Michael Heidelberger, and the assistance of Dr. Ephraim Otero-Ruiz, Dr. Konrad Hsu, Mrs. Malinda Getty Winans, Mrs. Mildred Rothenberg, Miss Joan Tierney, Mr. Rolland Siegel, and Miss Dolores Lawlor.

\section{REFERENCES}

1. Werner, S. C. Prolonged injection of a thyrotropin extract without development of refractoriness. Proc. Soc. exp. Biol. (N.Y.) 1936, 34, 390.

2. Werner, S. C. Antibody nature of refractoriness to injections of hypophyseal extracts containing thyro- 
tropic hormone. Proc. Soc. exp. Biol. (N.Y.) 1936, 34, 392.

3. Collip, J. B., and Anderson, E. M. Production of serum inhibitory to thyrotropic hormone. Lancet 1934, 1, 76.

4. Werner, S. C. The thyrotropic hormone and the antihormone problem. Endocrinology 1938, 22, 291.

5. Cruickshank, B., and Currie, A. R. Localization of tissue antigens with the fluorescent antibody technique: Application to human anterior pituitary proteins. Immunology 1958, 1, 13.

6. Condliffe, P. G., and Bates, R. W., Chromatography of thyrotrophin on diethylamino ethyl-cellulose. Arch. Biochem. 1957, 68, 229.

7. Pierce, J. L., Carsten, M. E., and Wynston, L. K. The purification and chemistry of the thyroid stimulating hormone. Conference on Modern Concepts of Thyroid Physiology. N. Y. Acad. Sci., Nov. 5-7, 1959.

8. Bates, R. W., Garrison, M. M., and Howard, T. B. Extraction of thyrotropin from pituitary glands, mouse pituitary tumors, and blood plasma by percolation. Endocrinology 1959, 65, 7.

9. Freund, J., Lipton, M. M., and Morrison, L. R. Demyelination in the guinea pig in chronic allergic encephalomyelitis produced by injecting guinea pig brain in oil emulsion containing variant of Mycobacterium butyricum. Arch. Path. (Chicago) 1950, 50, 108.

10. Ouchterlony, O. Antigen-antibody reactions in gels: IV. Types of reactions in coordinated systems of diffusion. Acta path. microbiol. scand. 1953, 32, 231.

11. Grabar, P., and Williams, C. A. Méthode permettant l'étude conjuguée des propriétés électrophorétiques et immunochimiques d'un mélange de pro- téines. Application au sérum sanguin. Biochim. biophys. Acta 1953, 10, 193.

12. McKenzie, J. M. The bioassay of thyrotropin in serum. Endocrinology 1958, 63, 372.

13. Werner, S. C., Seegal, B. C., Otero-Ruiz, E., and Bates, R. W. Neutralization of human serum and pituitary thyrotropic fractions with antisera to bovine pituitary thyrotropin. Nature (Lond.) 1960, 185, 472.

14. Howe, P. E. The use of sodium sulfate as the globulin precipitant in the determination of proteins in blood. J. biol. Chem. 1921, 49, 93.

15. Osserman, E. F. A modified technique of immunoelectrophoresis facilitating the indentification of specific precipitin arcs. J. Immunol. 1960, 84, 93.

16. Henry, S., and Van Dyke, H. B. A study of the antibodies produced in response to purified preparations of sheep interstitial cell stimulating hormone. J. Endocr. 1958, 16, 310.

17. Hayashida, T., and $\mathrm{Li}, \mathrm{C}$. H. A comparative immunological study of pituitary growth hormone from various species. Endocrinology 1959, 65, 944.

18. Korngold, L., and van Leeuwen, G. The formation of multiple zones of precipitate by one antigen; an immunological explanation. Int. Arch. Allergy 1959, 15, 278.

19. Lapresle, C. Etude de la dégradation de la sérumalbumine humaine par un extract de rate de lapin: Mise en évidence de trois groupements spécifiques différents dans le motif antigénique de l'albumine humaine et de trois anticorps correspondants dans le sérum de lapin anti-albumine humaine. Ann. Inst. Pasteur. 1955, 89, 654.

20. Carsten, M. E., and Pierce, J. S. Starch-gel electrophoresis and chromatography in the purification of beef thyrotropic hormone. J. biol. Chem. 1960, 235, 78. 